\title{
THE RELATIONSHIP BETWEEN ARTERIAL STIFFNESS AND 25-(OH) VITAMIN D, FGF 23 IN MAINTENANCE HEMODIALYSIS PATIENTS
}

\section{KRONIKK HEMODIYYALİZ HASTALARINDA ARTERİYEL SERTLİK İLE 25- (OH) VİTAMİN D, FGF 23 ARASINDAKİ İLIŞKİ}

Suleyman KARAKOSE ${ }^{1}$, Zeynep BAL ${ }^{2}$, Burak SAYIN ${ }^{2}$, Mehtap ERKMEN AKDOĞAN² ${ }^{2}$, Dilek GOKUSTUN ${ }^{3}$, Emre TUTAL ${ }^{2}$, Siren SEZER ${ }^{2}$

\begin{abstract}
AIM: Vascular calcification (VC) is highly prevalent in maintenance hemodialysis (MHD) population and increasing evidence indicates that abnormalities in mineral metabolism are closely associated with VC and increased mortality in chronic kidney disease (CKD) patients. In our study, we aimed to determine whether high Fibroblast growth factor-23 (FGF-23) and low $25(\mathrm{OH})$ Vitamin $\mathrm{D}$ levels are a result of high calcium load and whether there is a relationship between $25(\mathrm{OH})$ Vitamin D levels and arterial stiffness in CKD patients.
\end{abstract}

MATERIAL AND METHODS: One hundred and seventeen patients who were receiving MHD 3 times a week for at least 24 months were selected and followed up for 12 months and laboratory results were recorded from patient files. We analyzed the influence of a yearlong cumulative calcium and therapeutic vitamin $\mathrm{D}$ (paricalcitol and calcitriol) intake and serum FGF-23 level on endogenous 25(OH)D levels and the impacts of these parameters on the change in annual pulse wave velocity (PWV) measurement results in MHD patients.

RESULTS: Elementary calcium dose was significantly higher in vitamin $\mathrm{D}$ insufficiency group than control group $(\mathrm{P}=0.014)$. Serum levels of FGF-23 were positively correlated with duration of HD $(\mathrm{P}=0.001)$, mean parathyroid hormone $(\mathrm{PTH})(\mathrm{P}=0.001)$, mean phosphorus $(\mathrm{P})(\mathrm{P}=0.009)$ and mean CaXP $(\mathrm{P}=0.006)$. Baseline PWV measurement were similar between two groups, however patients in insufficiency group had higher 12th month PWV measurements compared to control group $(\mathrm{P}=0.034)$.

CONCLUSION: Calcium could increase serum FGF23 levels by indeterminate mechanisms independently of serum phosphorus level. Additionally, elevated FGF-23 level was found to be insulting a decline in vitamin $\mathrm{D}$ levels which may cause $\mathrm{VC}$ and stiffening of the arteries and resulting higher PWV measurements.

Keywords: Calcium load, FGF-23, Vascular calcification, 25-Hydroxy Vitamin D

\section{ÖZET}

AMAÇ: Vasküler kalsifikasyon (VK) kronik hemodiyaliz hastalarında $(\mathrm{KHH})$ oldukça yaygındır ve artan kanıtlar, mineral metabolizmasındaki anormalliklerin $\mathrm{VK}$ ve artmış mortalite ile yakından ilişkili olduğunu göstermektedir. Çalıșmamızda yüksek Fibroblast growth factor-23 (FGF-23) ve düşük 25(OH) Vitamin D düzeylerinin yüksek kalsiyum yükünün bir sonucu olup olmadığını ve KHH'da 25(OH) Vitamin D düzeyleri ile arteriyel sertlik arasında bir ilişki olup olmadığını incelemeyi amaçladık.

GEREÇ VE YÖNTEMLER: En az 24 aydır haftada 3 kez olmak üzere kronik hemodiyaliz programında olan yüz on yedi hasta seçildi ve 12 ay boyunca takip edildi. Laboratuar sonuçları hasta dosyalarından kaydedildi. Bir yıllık kümülatif kalsiyum $(\mathrm{Ca})$ ve terapötik D vitamini (parikalsitol ve kalsitriol) alımının ve serum FGF-23 seviyesinin 25(OH) Vitamin D seviyeleri üzerindeki etkisini ve bu parametrelerin yıllık pulse wave velocity (PWV) ölçüm sonuçlarındaki değişim üzerindeki etkilerini analiz ettik.

BULGULAR: Bazal kalsiyum dozu $\mathrm{D}$ vitamini yetersiz olan grupta kontrol grubuna göre anlamlı olarak yüksek bulundu $(\mathrm{P}=0,014)$. FGF-23'ün serum seviyesi hemodiyaliz süresi $(\mathrm{P}=0,001)$, ortalama paratiroid hormon $(\mathrm{PTH})(\mathrm{P}=0,001)$, ortalama fosfor $(\mathrm{P})(\mathrm{P}=0,009)$ ve ortalama CaXP $(\mathrm{P}=0,006)$ ile pozitif korelasyon gösterdi. Başlangıçtaki PWV ölçümü iki grup arasında benzerdi, ancak yetersizlik grubundaki hastalarda kontrol grubuna göre 12. aydaki PWV ölçümleri daha yüksekti $(\mathrm{P}=0,034)$.

SONUÇ: Kalsiyum, serum fosfor seviyesinden bağımsız olarak belirsiz mekanizmalar ile serum FGF23 seviyelerini artırabilir. Ek olarak, yüksek FGF-23 düzeylerinin vitamin D seviyelerinde düşüşe neden olarak VK'na ve arterlerin sertleşmesine yol açarak daha yüksek PWV ölçümlerine neden olabileceği bulunmuştur.

Anahtar kelimeler: Kalsiyum yükü, FGF-23, Vasküler kalsifikasyon, 25-Hidroksi Vitamin D

\footnotetext{
${ }^{1}$ Nephrology Department, University of Health Sciences, Konya Research and Training Hospital, Konya, Turkey

${ }^{2}$ Nephrology Department, Baskent University Faculty of Medicine, Ankara, Turkey

${ }^{3}$ Internal Medicine Department, Baskent University Faculty of Medicine, Ankara, Turkey
}

Geliș Tarihi / Submitted : Mart 2020 / March 2020

Kabul Tarihi / Accepted : Eylül 2020 / September 2020

\author{
Sorumlu Yazar / Corresponding Author: \\ Suleyman KARAKOSE \\ Nephrology Department, University of Health Sciences, Konya Research and Training \\ Hospital, Konya, Turkey \\ Phone: +903322210000 Fax: +90 3323211854 \\ E-mail: suleymankarakose@yahoo.com
}

\author{
Yazar Bilgileri /Author Information: \\ Suleyman KARAKOSE (ORCID: 0000-0003-4680-7435), \\ Zeynep BAL (ORCID: 0000-0002-9237-7619) E-mail: zeynepberki@yahoo.com, \\ Burak SAYIN (ORCID: 0000-0001-8287-6572) E-mail: buraksayin@hotmail.com, \\ Mehtap Erkmen AKDOĞAN (ORCID: 0000-0003-3377-7214) E-mail: mehtap94@yahoo.com, \\ Dilek GOKUSTUN (ORCID: 0000-0002-4573-0352) E-mail: drgokustun@hotmail.com, \\ Emre TUTAL (ORCID: 0000-0001-9747-9414) E-mail: emretutal@gmail.com, \\ Siren SEZER (ORCID: 0000-0002-7326-8388) E-mail:sirensezer@hotmail.com
}

All procedures performed in this study involving human participants were in accordance with the ethical standards of the Ethics Committee of Başkent University Faculty of Medicine, where the studies were conducted (approval number: KA11/255), and with the 1964 Helsinki Declaration and its later amendments or comparable ethical standards. 


\section{INTRODUCTION}

Cardiovascular $(\mathrm{CV})$ disease is the leading cause of death among chronic kidney disease (CKD) patients $(1,2)$. Vascular calcification (VC) is highly prevalent in maintenance hemodialysis (MHD) population and increasing evidence indicates that abnormalities in mineral metabolism such as hyperphosphatemia, hypercalcemia, high calcium-phosphorus product and secondary hyperparathyroidism are closely associated with VC and increased mortality in CKD patients (3). Arterial stiffness is a predictor of cardiovascular events in CKD population. Pulse wave velocity (PWV) is a non-invasive, reproducible and inexpensive diagnostic tool to determine arterial wave reflection, subclinical arterial disease and arterial stiffness (4).

Patients with renal failure have low serum 25-hydroxyvitamin D [25(OH)] because they usually have decreased exposure to sunlight, have reduced ingestion of foods that are natural sources of vitamin D, and insufficient endogenous vitamin $\mathrm{D}$ synthesis in the skin (5). Both the endothelial and smooth muscle cells of the vascular wall have local 1- $\alpha$-hydroxylase activity and vitamin $\mathrm{D}$ receptors (VDR). Activation of these receptors causes anti-inflammatory, anti-proliferative and antifibrotic effects through reduced expression of cytokines and calcification promoter metalloproteinases and through increased expression of calcification inhibitors. Reduced vitamin D levels in CKD patients are closely associated with endothelial dysfunction, VC, arterial stiffness and high CV mortality $(6,7)$.

Serum Fibroblast Growth Factor-23 (FGF-23) secreted by osteoblasts, is a phospathuric hormone that inhibits 1- $\alpha$-hydroxylase and prevents conversion of $25-\mathrm{OH}$ vitamin D to $1,25(\mathrm{OH})$ vitamin D. FGF-23 levels increase and serum vitamin $\mathrm{D}$ levels decrease long before serum phosphate levels increment during the progression of CKD. Although increased serum phosphorus is the primary trigger for FGF-23; it had been speculated that other factors including calcium, renin-angiotensin-aldosterone system and inflammation could also influence FGF-23 synthesis (79). Recent studies suggested that there was a differential influence of phosphate binders on serum FGF-23 level. It has hypothesized that not only accumulation of phosphorus, but also deposition of calcium could have influence on serum FGF-23 levels (10).

In our study, we hypothesized that high FGF-23 and low endogeneous vitamin $D$ levels might be a result of high calcium load and aimed to determine the relationship between endogenous vitamin $\mathrm{D}$ levels and arterial stiffness in CKD patients. We also hypothesized that the drugs used in renal osteodystrophy could have an impact on low endogenous vitamin D levels in dialysis patients. We analysed the influence of a yearlong cumulative calcium and theraupetic vitamin $\mathrm{D}$ (paricalcitol and calcitriol) intake, and serum FGF23 level on endogenous $25(\mathrm{OH})$ levels and the impacts of these parameters on the change in annual PWV measurement results in MHD patients.

\section{Patients and Methods \\ Study Population}

This is an observational, prospective, single-center study. One hundred and seventeen patients who were receiving MHD 3 times a week for at least 24 months were selected from 350 patients according to the following exclusion criteria; Kt/V $<1.4$, chronic inflammation of unknown etiology, malign disease history in past 5 years, having chronic liver disease, using calcimimetics, severe hyperparathyroidism (serum PTH $>800 \mathrm{pg} / \mathrm{mL}$ ), using drugs that could affect calcium or bone metabolism (calcitonin, bisphosphonates, and glucocorticoids), pregnancy or breastfeeding, prior parathyroidectomy procedure, patients receiving any other form of vitamin $\mathrm{D}$, including "native" or as a dietary supplement, patients who were diagnosed as malnourished, having inflammatory bowel disease. The laboratory results were recorded from patient files. The institutional review board approved the protocol used in this study. Definitions of insufficiency $(<30 \mathrm{ng} / \mathrm{mL})$ and normal values $(>30 \mathrm{ng} / \mathrm{mL})$ for $25(\mathrm{OH}) \mathrm{D}$ were based on KDIGO guidelines (11). Patients were divided into two groups according to $25(\mathrm{OH}) \mathrm{D}$ levels: Insufficiency (INS group, $25(\mathrm{OH}) \mathrm{D}<30 \mathrm{ng} / \mathrm{mL}$ ) and control group (CON group, $25(\mathrm{OH}) \mathrm{D}>30 \mathrm{ng} / \mathrm{mL})$.

Biochemical Analysis and Pulse Wave Velocity Analysis Blood sample was obtained directly through an arteriovenous fistula or central catheter on a mid-week non-dialysis day. Predialysis serum concentrations of calcium, phosphorus, alkaline phosphatase, albumin, hemoglobin, $\mathrm{C}$ reactive protein (CRP) levels were assessed and recorded monthly. PTH, bicarbonate and uric acid levels were measured every 3 months. Serum FGF-23 and 25(OH)D levels were measured at the end of the one year follow-up period. Serum samples were separated from clotted blood by immediate centrifugation ( $1500 \mathrm{~g}$ for $10 \mathrm{~min}$ ), aliquoted and stored at $-80^{\circ} \mathrm{C}$ until assay. Serum levels of FGF-23 were measured by an enzyme-linked immunosorbent assay (ELISA) using commercially available standard kits (Uscn Life Science Inc., Wuhan, P.R China). Serum $25(\mathrm{OH}) \mathrm{D}$ was measured with a high-performance liquid chromatography (HPLC) method provided by "IMMUCHROM GmbH" (Heppenheim, Germany).

PWV were assessed at the beginning of study and end of the follow-up period. Femoral and carotid artery wave forms were consecutively obtained using the SphygmoCor apparatus and customized software. Continuous pulse pressure wave signals were recorded with a tonometer positioned at both the base of the right common carotid artery and over the femoral artery (Millar arterial pressure tonometer, SphygmoCor machine; pulse wave velocity (PWV; PWV Inc., Weastmead, Sydney, NSW, Australia). Distances from the carotid sampling sites to the manubrium of the sternum 
and from manubrium sternum to femoral artery were measured. The mean transit time $(\mathrm{t})$ between the feet of simultaneously recorded waves was determined from 10 consecutive cardiac cycles. PWV was calculated from the distance between measurement points and the measured time delay as follows: $\mathrm{PWV}=\mathrm{D} / \mathrm{t}(\mathrm{D}$, distance in meters; $t$, time in seconds). The methodology was previously described and validated (12).

\section{Vitamin D Receptor Activator and Phosphate Binder Treatment}

One hundred and nine $(93.1 \%)$ patients were receiving active forms of vitamin $\mathrm{D}: 53.8 \%(\mathrm{n}=63)$ intravenous (iv) calcitriol, with a mean dose of $0.5 \pm 0.5 \mu \mathrm{g} /$ week, and $39.3 \%(n=46)$ iv paricalcitol, with a mean dose of $5.9 \pm 4.2$ $\mu \mathrm{g} /$ week. All patients were under therapy with phosphate binders: 31 (26.5\%) were taking calcium carbonate, 28 (23.9\%) were receiving sevelamer and $58(49.6 \%)$ were taking combined phosphate binder medication.

\section{Statistical Analysis}

The Statistical Package for Social Sciences version of 21.0 for Windows (SPSS Inc., Chicago, IL, USA) was used for the data analysis. Data were submitted to a frequency distribution analysis using the Kolmogorov-Smirnov test. Values displaying a normal distribution are expressed as mean $\pm S D$, and values with a skewed distribution are expressed as median (interquartile range). Differences between numeric variables were tested with the independent-samples Student t-test or Mann-Whitney $\mathrm{U}$ test, whichever was appropriate. Related data were compared using the paired samples t-test or Wilcoxon test, whichever was appropriate. Categorical data were compared using the chi-square test. A value was considered statistically significant at $\mathrm{P}<0.05$.

\section{Ethical Approval}

All procedures performed in this study involving human participants were in accordance with the ethical standards of the Ethics Committee of Başkent University Faculty of Medicine, where the studies were conducted (approval number: KA11/255), and with the 1964 Helsinki Declaration and its later amendments or comparable ethical standards.

\section{RESULTS}

Demographic and initial clinical characteristics of the insufficiency and control groups were similar (Table 1).

Table 1. Demographical and clinical characteristics of all subjects, comparison of laboratory findings and baseline and $12^{\text {th }}$ month of pulse wave velocity measurements of the groups

\begin{tabular}{|c|c|c|c|}
\hline & $\begin{array}{l}\text { Insufficiency } \\
\text { Group (n:91) }\end{array}$ & $\begin{array}{c}\text { Control } \\
\text { Group (n:26) }\end{array}$ & $P$ value \\
\hline Age (year) & $54.5 \pm 13.2$ & $51.8 \pm 14.6$ & 0.360 \\
\hline Gender $(F)$ & $41,45.1 \%$ & $9,34.6 \%$ & 0.345 \\
\hline Duration of dialysis (month) & 84 & 96 & 0.443 \\
\hline $\begin{array}{l}\text { Etiology of CKD } \\
\text { DM } \\
\text { HT } \\
\text { GN } \\
\text { PCKD } \\
\text { Other } \\
\text { Unknown }\end{array}$ & $\begin{array}{c}24,26.4 \% \\
17,18.7 \% \\
10,11 \% \\
6,6.6 \% \\
21,23.1 \% \\
13,14.3 \%\end{array}$ & $\begin{array}{c}8,30.8 \% \\
1,3.8 \% \\
5, \quad 19.2 \% \\
1, \quad 3.8 \% \\
7,26.9 \% \\
4,15.4 \%\end{array}$ & 0.732 \\
\hline Mean PTH & $550.7(561.2)$ & $621.2(350.7)$ & 0.943 \\
\hline Mean Ca & $8.9 \pm 0.53$ & $9.0 \pm 0.51$ & 0.563 \\
\hline Mean P & $5.8 \pm 0.89$ & $5.3 \pm 0.87$ & 0.006 \\
\hline Mean CaxP & $52.2 \pm 8.7$ & $47.7 \pm 9.1$ & 0.023 \\
\hline Mean ALP (U/L) & $112.1(84.3)$ & $106(86)$ & 0.653 \\
\hline Mean albumin(g/dL) & $3.8 \pm 0.25$ & $3.8 \pm 0.22$ & 0.486 \\
\hline Mean Hemoglobin (g/dL) & $11.1(1.1)$ & $10.9(1.2)$ & 0.350 \\
\hline Mean CRP(mg/L) & $6.3(10.6)$ & $6.5(14.1)$ & 0.495 \\
\hline Mean $\mathrm{HCO}_{3}$ & $17.2 \pm 2.4$ & $17.5 \pm 1.9$ & 0.631 \\
\hline Uric acid & $6.9 \pm 0.9$ & $6.5 \pm 0.8$ & 0.162 \\
\hline FGF-23 (pg/mL) & $25(42.4)$ & $15.6(23.5)$ & 0.039 \\
\hline 25-OH-Vitamin D $(\mu \mathrm{g} / \mathrm{L})$ & $21(7)$ & $33.5(11.5)$ & 0.001 \\
\hline $\mathrm{PWV}_{\text {baseline }}(\mathrm{m} / \mathrm{s})$ & $7.7 \pm 2.3$ & $7.1 \pm 1.8$ & 0.177 \\
\hline PWV 12 th month $(\mathrm{m} / \mathrm{s})$ & $8.4 \pm 2.8$ & $7.1 \pm 1.9$ & 0.034 \\
\hline
\end{tabular}

$\mathrm{CKD}=$ Chronic Kidney Disease, $\mathrm{DM}=$ Diabetes mellitus, $\mathrm{HT}=$ Hypertension, GN=Glomerulonephritis, $\mathrm{PCKD}=$ Polycystic Kidney Disease, PWV=Pulse Wave Velocity 
The insufficiency group had significantly higher $\mathrm{P}$ and $\mathrm{Ca}$ ' $\mathrm{P}$ levels as compared to the control group ( $\mathrm{P}$ $=0.006, \mathrm{P}=0.023$ respectively; Table 1$)$. We found no significant differences in the mean values of $\mathrm{PTH}, \mathrm{Ca}$, ALP, albumin, hemoglobin, CRP, bicarbonate and uric acid between the groups (Table 1). FGF-23 level was significantly higher in INS group than in control group $(\mathrm{P}=0.039)$. PWV multivariate regression analysis results at the 12th month were given in Table 2.

Table 2. PWV multivariate regression analysis at the $12^{\text {th }}$ month

\begin{tabular}{|c|c|c|c|c|}
\hline \multirow{2}{*}{ Variables } & \multicolumn{4}{|c|}{ Multivariate Analysis } \\
\hline & B & Wald & OR $(95 \% \mathrm{CI})$ & $\mathbf{P}$ \\
\hline Age & 0.068 & 4.920 & $\begin{array}{c}1.071 \\
(1.014-1.089)\end{array}$ & 0.027 \\
\hline Mean Ca & 0.564 & 0.504 & $\begin{array}{c}1.757 \\
(0.980-2.451)\end{array}$ & 0.478 \\
\hline Mean P & 0.877 & 0.909 & $\begin{array}{c}2.404 \\
(0.478-4.911)\end{array}$ & 0.341 \\
\hline Mean CaxP & -0.179 & 3.326 & $\begin{array}{c}0.836 \\
(0.803-0.868)\end{array}$ & 0.681 \\
\hline FGF-23 & -0.022 & 0.201 & $\begin{array}{c}0.998 \\
(0.990-1.006)\end{array}$ & 0.655 \\
\hline $\begin{array}{l}25-\mathrm{OH} \\
\text {-VitaminD }\end{array}$ & -0.781 & 3.619 & $\begin{array}{c}0.925 \\
(0.890-0.960)\end{array}$ & 0.048 \\
\hline
\end{tabular}

There was no significant difference in terms of mean equivalent dose of vitamin $\mathrm{D}$ receptor activator and sevelamer dose between two groups. Administered elementary calcium dose was significantly higher in insufficiency group than control group $(\mathrm{P}=0.014$, Table $3)$. Type of Vitamin D Receptor Activator (VDRA) treatment was also similar between two groups (Table 3).

Serum levels of FGF-23 were positively correlated with duration of $\mathrm{HD}(\mathrm{P}=0.001)$, mean $\mathrm{PTH}(\mathrm{P}=0.001)$, mean $\mathrm{P}(\mathrm{P}=0.009)$ and mean $\mathrm{CaXP}(\mathrm{P}=0.006)$. Serum levels of $25(\mathrm{OH}) \mathrm{D}$ were negatively correlated with mean phosphorus $(\mathrm{P}=0.039)$, mean administered elementary calcium dose $(\mathrm{P}=0.017)$ and $\mathrm{PWV} 2(\mathrm{P}=0.035)$ (Fig1). On multivariate regression analysis, levels of $25(\mathrm{OH}) \mathrm{D}$ were independently associated with the adjusted dose of elementary calcium $(\mathrm{P}=0.048)$.

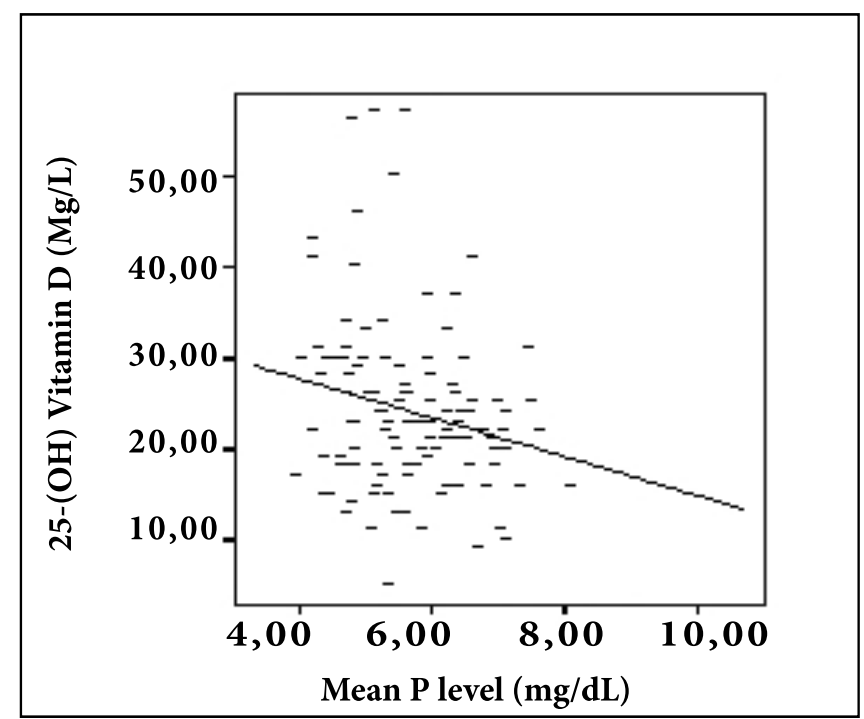

Figure 1. Correlations between 25-hydroxyvitamin D3 serum levels and mean $\mathrm{P}$, mean elementary calcium and PWV 12th month

Table 3. Adjusted equivalent Vitamin $\mathrm{D}$ dose, phosphate binder dose for two groups and comparison of groups according to the type of VDRA treatment

Median (IR)
n, \%

Mean administered equivalent Vitamin D dose (mcg/ week)
Insufficiency Group

(n:91)

$3.4 \pm 4.9$

$5.6 \pm 8.1$

$3.6 \pm 5.2$

$12.4 \pm 25.5$

$9(34.6 \%)$

Patients under paricalcitol treatment (n, \%)

$37(40.7 \%)$
$48(52.7 \%)$
$15(57.7 \%)$
0.592
Patients under calcitriol treatment (n, \%)
$6(6.6 \%)$
$2(7.7 \%)$
Patients without VDRA treatment (n, \%)

$6(6.6 \%)-2(7.7 \%)$

VDRA=Vitamin D Receptor Activator 


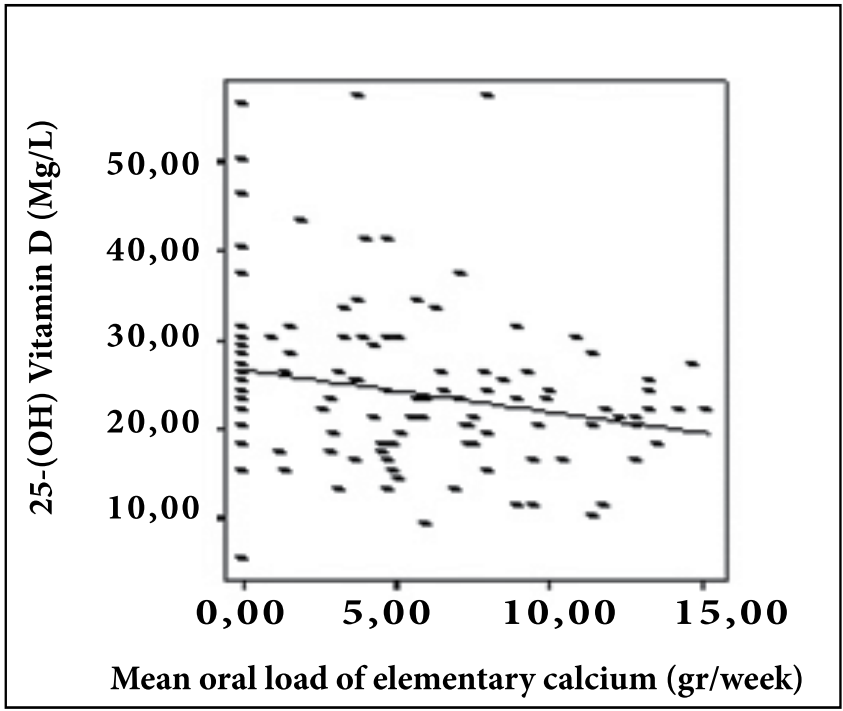

Figure 1. Correlations between 25-hydroxyvitamin D3 serum levels and mean $P$, mean elementary calcium and PWV 12th month

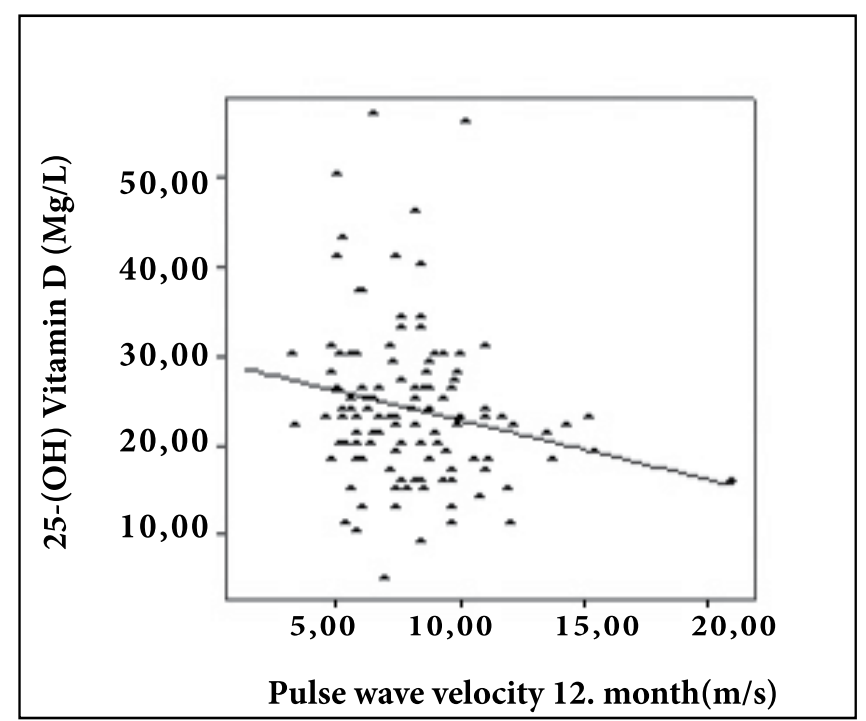

Figure 1. Correlations between 25-hydroxyvitamin D3 serum levels and mean $P$, mean elementary calcium and PWV 12th month

\section{DISCUSSION}

Patients with renal failure have low serum 25 -hydroxyvitamin D [25(OH)D] because they are relatively inactive, have decreased exposure to sunlight, have reduced ingestion of foods that are natural sources of vitamin $\mathrm{D}$, and the endogenous synthesis of vitamin $\mathrm{D}$ in the skin is also compromised in uremic patients (5). Reduced vitamin D levels have also been recently associated with arterial stiffness in dialysis patients (13). According to our results, patients who have low vitamin $\mathrm{D}$ seem to be a major determinant for arterial stiffness in CKD patients ongoing hemodialysis. Patients who have low vitamin D levels were found to have significantly higher PWV measurements compared to patients who have normal or high vitamin D levels. PWV of the 2 groups were similar at baseline but after 12 months of follow-up; vitamin D insufficiency group exhibited a significant increase compared to the control group who had stable PWV measurements.

We hypothesized that the drugs used for renal osteodystrophy could have an impact on arterial stiffness and we analyzed the influence of cumulative calcium-based agents, sevelamer and vitamin D analogue treatments of the groups. Serum FGF-23 levels were also compared between the 2 groups as a prognostic marker of CV disease in CKD. Phosphatebinders have different effects on FGF-23 levels. Recent studies showed that lanthanum carbonate and sevelamer were effective in reducing FGF23 levels; this effect was not observed with calcium carbonate $(14,15)$. In this context, calcium could increase serum FGF23 levels by indeterminate mechanisms independently of serum phosphate level. Additionally, elevated FGF-23 levels were found to be associated with a decline in vitamin D levels which may cause VC and stiffness of the arteries and resulting higher PWV measurements. Though we could not show a direct relationship between FGF23 levels and phosphate binders, we showed that serum levels of vitamin D were found to be negatively correlated with mean oral load of elementary calcium and PWV measurements. Moreover, on multivariate analysis, serum $25(\mathrm{OH})$ D levels were independently associated with the mean administered dose of elementary calcium load in 12 months period. In literature, the relationship between FGF23 with phosphate binders was generally shown in predialysis patients $(16,17)$. In dialysis patients this relationship has not yet been clearly demonstrated in this respect our study was valuable. Park KM. et al. reported that there was no association between serum $25(\mathrm{OH}) \mathrm{D}$ levels and arterial stiffness in non-dialysis CKD and MHD patients (18); but their set point for $25(\mathrm{OH}) \mathrm{D}$ was lower than KDIGO recommendations. On the other hand, Seker T et al. reported that $25(\mathrm{OH})$ $D$ levels were associated with increased arterial stiffness in healthy subjects (19).

We revealed that patients who have low vitamin $\mathrm{D}$ levels are prone to higher calcitriol or paricalcitol and calcium-based phosphorus binding agents. This state causes higher calcium phosphorus exposure which results a higher risk for $\mathrm{CV}$ mortality. The mean administered active vitamin $\mathrm{D}$ receptor activator and the mean oral load of sevelamer doses were similar for the two groups during the follow-up period. Oral cumulative load of elementary calcium was significantly higher in the vitamin D insufficiency group compared to control group.

Our study had some limitations due to the fact of being an observational and cross-sectional study. Although we revealed that low vitamin $\mathrm{D}$ levels are closely associated with accelerated arterial stiffness in CKD patients, we do not have enough data to comment on whether low vitamin D levels was a reason or a result of arterial stiffness and higher FGF-23 levels in our study 
group. Our main drawbacks are relatively small number of groups, and vitamin D and FGF levels were measured cross-sectional and indirectly shows the relationship between calcium supplementation and FGF-23/vitamin $\mathrm{D}$ axis. Nevertheless, we revealed a criticizing view to the classical treatment of renal osteodystrophy. Largerscale longitudinal multicenter studies are needed to confirm our results and to evaluate the possible outcome of treatments with vitamin $\mathrm{D}$, calcium-based and calcium-sparing phosphate binding agents on FGF-23 and arterial stiffness.

Targeting to control renal osteodystrophy and serum PTH levels in $\mathrm{CKD}$ patients ongoing $\mathrm{HD}$, high phosphorus levels and minimum calcium supplementation may create higher FGF-23 levels and worsening of arterial stiffness by accelerating calcium-phosphorus product and vascular calcification. The positive effect of calciumsparing phosphate-binding agents on $\mathrm{VC}$ and arterial stiffness may be the result of lower cumulative calcium intake and the better control of calcium-phosphorus product. We suggested that better phosphorus control and reducing calcium supplementation in CKD patients should be a goal in renal osteodystrophy treatment in $\mathrm{CKD}$ patients for avoiding CV events.

\section{REFERENCES}

1.)Sarnak MJ, Levey AS, Schoolwerth AC, et al. Kidney disease as a risk factor for development of cardiovascular disease: a statement from the American Heart Association Councils on Kidney in Cardiovascular Disease, High Blood Pressure Research, Clinical Cardiology, and Epidemiology and Prevention. Circulation 2003; 108: 2154-2169.

2.)Matsushita $K$, van der Velde $M$, Astor BC, et al. Association of estimated glomerular filtration rate and albuminuria with allcause and cardiovascular mortality in general population cohorts: a collaborative meta-analysis. Lancet 2010; 375: 2073-2081.

3.) Vervloet $M$, Cozzolino M. Vascular calcification in chronic kidney disease: different bricks in the wall? Kidney Int. 2017; 91: 808-817.

4.)Suzuki H, Inoue T, Dogi $M$, et al. Role of Pulse Wave Velocity in Patients with Chronic Kidney Disease Stages 3-5 on Long-Term Follow-Up. Pulse (Basel) 2014; 2: 1-10.
5.)Jean G , Souberbielle JC, Chazot C. Vitamin D in Chronic Kidney Disease and Dialysis Patients. Nutrients. 2017; 9: 328.

6.)Molina P, Carrero JJ, Bover J, et al. Vitamin D, a modulator of musculoskeletal health in chronic kidney disease. J Cachexia Sarcopenia Muscle. 2017; 8: 686-701.

7.)Obi Y, Hamano T, Isaka Y. Prevalence and prognostic implications of vitamin $\mathrm{D}$ deficiency in chronic kidney disease. Dis Markers. 2015; 2015:868961.

8.) Olauson H, Larsson TE. FGF23 and Klotho in chronic kidney disease. Curr Opin Nephrol Hypertens. 2013; 22: 397-404.

9.)de Borst MH, Vervloet MG, ter Wee PM, et al. Cross talk between the renin-angiotensin-aldosterone system and vitamin D-FGF-23klotho in chronic kidney disease. J Am Soc Nephrol. 2011; 22: 1603-9. 10.)Kamr AM, Dembek KA, Hildreth BE et al. The FGF-23/klotho axis and its relationship with phosphorus, calcium, vitamin $\mathrm{D}$, $\mathrm{PTH}$, aldosterone, severity of disease, and outcome in hospitalized foals. Equine Vet J. 2018; 50: 739-746.

11.)Kidney Disease Improving Global Outcomes (KDIGO) CKD Work Group KDIGO 2012 clinical practice guideline for the evaluation and management of chronic kidney disease. Kidney Inter Suppl 2013; 3: 73-90.

12.)Mackenzie IS, Wilkinson IB, Cockcroft JR. Assessment of arterial stiffness in clinical practice. QJM. 2002; 95(2): 67-74.

13.)London GM, Guérin AP, Verbeke FH, et al. Mineral metabolism and arterial functions in end-stage renal disease: potential role of 25-hydroxyvitamin D deficiency. J Am Soc Nephrol. 2007; 18: 613-20. 14.)Kalaitzidis RG, Elisaf MS. Hyperphosphatemia and phosphate binders: effectiveness and safety. Curr Med Res Opin. 2014; 30: 109-12. 15.)Ritz E, Gross ML. Hyperphosphatemia in renal failure. Blood Purif. 2005; 23: 6-9.

16.)Yilmaz MI, Sonmez A, Saglam M, et al. Comparison of calcium acetate and sevelamer on vascular function and fibroblast growth factor 23 in CKD patients: a randomized clinical trial. Am J Kidney Dis. 2012; 59: 177-85.

17.)Oliveira RB, Cancela AL, Graciolli FG, et al. Early control of PTH and FGF23 in normophosphatemic CKD patients: a new target in CKD-MBD therapy? Clin J Am Soc Nephrol. 2010; 5: 286-91.

18.)Kyung Mi Park, Hak Hoon Jun, Jinkun Bae, et al. 25-hydroxyvitamin D Levels was not Associated with Blood Pressure and Arterial Stiffness in Patients with Chronic Kidney Disease. BMC Nephrology 2017; 18: 28.

19.)Seker T, Gür M, Kuloglu O, et al. Serum 25-hydroxyvitamin D is associated with both arterial and ventricular stiffness in healthy subjects. Journal of Cardiology 2013; 62: 361-365.

\footnotetext{
Ankara Eğt. Arş. Hast. Derg. (Med. J. Ankara Tr. Res. Hosp.), 2020 ; 53(3) : 215-220

All procedures performed in this study involving human participants were in accordance with the ethical standards of the Ethics Committee of Başkent University Faculty of Medicine, where the studies were conducted (approval number: KA11/255), and with the 1964 Helsinki Declaration and its later amendments or comparable ethical standards.
} 